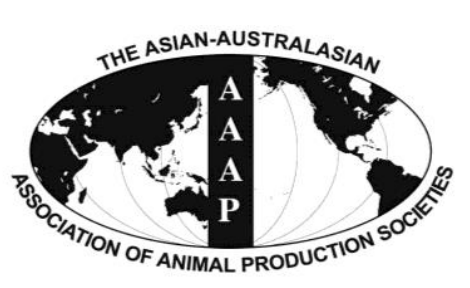

Open Access

Asian Australas. J. Anim. Sci.

Vol. 28, No. 8 : 1133-1139 August 2015

http://dx.doi.org/10.5713/ajas.14.0960

www.ajas.info

pISSN 1011-2367 elSSN 1976-5517

\title{
The Technical and Financial Effects of Parenteral Supplementation with Selenium and Vitamin E during Late Pregnancy and the Early Lactation Period on the Productivity of Dairy Cattle
}

\author{
T. Bayril*, A. S. Yildiz ${ }^{1}$, F. Akdemir ${ }^{2}$, C. Yalcin ${ }^{1}$, M. Köse ${ }^{3}$, and O. Yilmaz ${ }^{4}$ \\ Department of Animal Husbandry, Faculty of Veterinary Medicine, Dicle University, Diyarbakir 21280, Turkey
}

\begin{abstract}
This study aimed to determine the effects of parenteral selenium (Se) and vitamin E supplementation on economic impact, milk yield, and some reproductive parameters in high-yield dairy cows in the dry period and in those at the beginning of lactation. At the beginning of the dry period, cows $(n=323)$ were randomly divided into three groups as follows: Treatment 1 (T1), Treatment 2 (T2), and Control (C). Cows in group T1 received this preparation 21 days before calving and on calving day, and cows in group T2 received it only on calving day. The cows in the control group did not receive this preparation. Supplementation with Se increased Se serum levels of cows treated at calving day $(\mathrm{p}<0.05)$. Differences in milk yield at all weeks and the electrical conductivity values at the 8th and 12th weeks were significant $(\mathrm{p}<0.05)$. Supplementation with Se and Vitamin E decreased the incidence of metritis, the number of services per conception and the service period, but had no effects on the incidence of retained fetal membrane. A partial budgeting analysis indicated that Se supplementation was economically profitable; cows in group T1 averaged $240.6 \$$ per cow, those in group T2 averaged 224.6\$ per cow. Supplementation with Se and Vitamin E has been found to increase serum Se levels, milk yield, and has positive effects on udder health by decreasing milk conductivity values and incidence of sub-clinical mastitis. (Key Words: Selenium, Vitamin E, Milk Yield, Reproductive Parameters, Partial Budget Analysis, Dairy Cattle)
\end{abstract}

\section{INTRODUCTION}

Milk yield and fertility are directly related to profitability in dairy farms. To sustain high milk yield, fertility must be kept at an optimal level. Very rapid metabolic and hormonal changes occur in the periparturient period, in which important events such as birth and involution of the uterus take place (Pryce et al., 2004).

\footnotetext{
* Corresponding Author: T. Bayril. Tel: +90-412-248-80-21, Fax: +90-412-248-80-20, E-mail: tbayril@ hotmail.com

${ }^{1}$ Department of Animal Health Economics and Management, Faculty of Veterinary Medicine, Dicle University, Diyarbakir 21280, Turkey.

${ }^{2}$ Department of Nutrition, Faculty of Fisheries, Inonu University, Malatya 44280, Turkey.

${ }^{3}$ Department of Obstetrics and Gynecology, Faculty of Veterinary Medicine, Dicle University, Diyarbakir 21280, Turkey.

${ }^{4}$ Department of Animal Husbandry, Faculty of Veterinary Medicine, Yuzuncu Yil University, Van 65280, Turkey.

Submitted Dec. 24, 2014; Revised Jan. 26, 2015; Accepted Feb. 27, 2015
}

Cows that are especially highly efficient are predisposed to metabolic, infectious and reproductive diseases during the periparturient period because of immune system suppression, rapid hormonal changes during birthing, and metabolic stress associated with lactation (Arslan and Tufan, 2010).

The periparturient period is a time during which dairy cows are at risk, and they are prone to diseases that could affect their productivity. Ketosis, hypocalcemia, fatty liver syndrome, retained placenta, metritis, mastitis and other related diseases occur frequently in this period (Wilde 2006). Due to immune system suppression during the periparturient period, such diseases cause decreases in productivity and even culling of cows (Roche et al., 2000; Roche, 2006). It is very important to pass smoothly through the periparturient period to maintain optimal milk yield and reproductive productivity during the new lactation period.

Vitamins and minerals are micro-nutrient components that play important functions in all organisms, especially 
during reproduction (Spears, 2000). In the periparturient period, Se and vitamin E (Vit E) may improve milk yield and fertility in predisposed cows because of their effects on the immune and antioxidative defense systems. Se enters the enzymatic anti-oxidant glutathione peroxidase, which enables the metabolization of intracellular hydroperoxides that are formed during normal intracellular metabolism (Arthur et al., 2003). The lack of Se has been reported to cause decreases in fertility, mastitis, reductions in milk yield, increases in the incidence of retained placenta, and loss of weight gain in calves (Brzezinska Slebodzinska et al., 1994; Vanegas et al., 2004). Vit $\mathrm{E}$ is a fat-soluble antioxidant and non-enzymatic compound that is essential for most animal organisms. Because of this, Vit $\mathrm{E}$ is a functional antioxidant that plays a role in the protection/defense of the integrity of cell membranes. It has been reported that the parenteral use of Se and Vit E during late pregnancy provides increased fertilization in the number of service per conception and pregnancy rate, decreased open days, ovarian cysts, incidence of mastitis and retained placenta (Harrison et al., 1984; Vanegas et al., 2004).

This study aimed to determine the effects of parenteral Se and Vit E application on economic impact, milk yield, and some reproductive parameters in high-yield dairy cows during the dry period and at the beginning of lactation.

\section{MATERIALS AND METHODS}

\section{The study area and animals}

The present study was conducted on a commercial dairy farm containing 1,900 lactating Holstein cows in the Turhal district of Tokat province, Turkey. The farm is located in the Mid-Black Sea region within $40^{\circ} 23^{\prime}$ north latitude and $36^{\circ} 5^{\prime}$ east longitude. The altitude of Turhal is $493 \mathrm{~m}$, the annual average temperature is $9^{\circ} \mathrm{C}$ to $12^{\circ} \mathrm{C}$, and the annual rainfall is $413.3 \mathrm{~mm}$.

\section{Management, feeding of the cows, and data recording}

A total of 323 Holstein dairy cows, each of which had given birth at least once, were enrolled in the study. In the dry period, cows were housed in free-stall barns in groups of 25 to 30 and fed two times daily at $12 \mathrm{~h}$ intervals with a mixed ration of corn silage, alfalfa hay, wheat straw and concentrate. Drinking water was provided ad libitum with automatic waterers. Cows were taken to individual birth boxes 5 days prior to calving. After the fifth day of calving, cows were housed in free-stall barns with automatic waterers, rubber bedding, and cooling system paddocks. In the lactation period, cows were fed ad libitum a total mixed ration (TMR) prepared with automatic mixer feeder (Unifit, Tekniktürk, İzmir, Turkey) after each milking. The diet formulated based on NRC (2001) recommendation for a $600 \mathrm{~kg}$ cow to produce $30 \mathrm{~kg} / \mathrm{d}$ of milk containing $3.5 \%$ of milk fat and $3.2 \%$ protein (Table 1). Cows were milked three times a day at approximately $8 \mathrm{~h}$ intervals by an automatic milking system (Rotary Magnum 90 Milking Parlor, Westfalia Surge, İzmir, Turkey). The individual milk yield of each cow, the electrical conductivity of the milk (Conductivity meters, Westfalia Surge, Turkey) and live weights (Taxatron, Westfalia Surge, Turkey) were measured with electronic systems and determined by the herd manager as part of a herd management program (Dairy Plan C21, Westfalia Surge, Turkey). Detection of estrus was performed with a pedometer (Activity meters, Westfalia Surge, Turkey) and increases in the activity of the cows, increases in the tone of the uteral cornus, and by the presence of graaf follicules on the ovaries, in addition to citings by the technicians.

\section{Experimental design}

At the beginning of the dry period, cows $(n=323)$ were randomly divided into three groups as follows: Treatment 1 (T1), Treatment 2 (T2) and Control (C). Ten milliliters of a commercial preparation (Selen E-Sol, Richter AG, Avusturya, $1 \mathrm{~mL}$ equivalent to $150.00 \mathrm{mg}$ DL-alpha tocopherol acetate and $1.67 \mathrm{mg}$ Pentahydrate-disodium selenite) was administered intramuscularly according to the prospectus. Cows in group $\mathrm{T} 1(\mathrm{n}=107, \mathrm{~W}=521.16 \pm 53.5$ $\mathrm{kg}$ ) received this preparation 21 days before calving and on calving day, and cows in group $\mathrm{T} 2(\mathrm{n}=107, \mathrm{~W}=$ $522.25 \pm 52.31 \mathrm{~kg}$ ) received it only on calving day. The cows in the control group $(\mathrm{n}=109, \mathrm{~W}=518.47 \pm 56.10 \mathrm{~kg}) \mathrm{did}$ not receive this preparation.

Ten $\mathrm{mL}$ of jugular blood samples were obtained from all cows to determine Se serum concentration 21 days before calving day (before injection) and on the 3rd day after calving. Blood samples were centrifuged at $3,500 \times$ g for 15 min and sera samples were stored at $-25^{\circ} \mathrm{C}$.

Table 1. Chemical composition of the basal diet in early lactation of dairy cow

\begin{tabular}{lc}
\hline Diet composition & $\begin{array}{c}\text { Lactation } \\
\text { (1 to } 90 \text { days) }\end{array}$ \\
\hline Crude protein (\% of DM) & 14.9 \\
Degradable protein (\% of CP) & 59.6 \\
Bypass protein (\% of CP) & 30.4 \\
Neutral detergent fiber (\% of DM ) & 40.2 \\
Acid detergent fiber (\% of DM ) & 22.2 \\
Starch (\% of DM) & 22.8 \\
Calcium (\% of DM) & 0.61 \\
Phosphorus (\% of DM) & 0.38 \\
Sodium (\% of DM) & 0.14 \\
Potassium (\% of DM) & 0.92 \\
Selenium (ppm) & 0.03 \\
Vitamin E (mg/kg of DM) & 15.0 \\
Net energy for lactation (Mcal/kg of DM) & 1.53 \\
\hline
\end{tabular}

DM, dry matter; $\mathrm{CP}$, crude protein. 
Se concentration in the serum of each cow was analyzed by atomic absorption spectrometry (Perkin-Elmer, Analyst 800, Kleve, Germany) with a hydride generator system (HG-GF-AAS) in combination with flow injection analysis (FIAS-400, Waltham, MA, USA) with EDL lamb (Dogukan et al., 2009). All samples were analyzed at least twice, and the results were averaged.

The average milk yield of the cows at 4, 8, 12, and 16 weeks after birth and the electrical conductivity of the milk were determined from the computer records.

The service period and number of services per conception (NSC), as well as the incidence of retained fetal membrane (RFM), clinical metritis and mastitis were taken from the computer records. Cows retaining the placenta for more than $12 \mathrm{~h}$ were considered as RFM. Metritis was determined by monitoring the abnormal accumulation of fluid at the base of the vagina during the vaginal examination. Subclinical mastitis was identified by examining the increase in milk viscosity by the Californian Mastitis Test from computer records for cows within 30 days postpartum that had an increased milk electrical conductivity.

\section{Statistical analyses}

SPSS 11.5 Statistical Software was used for statistical analyses. In order to determine the most suitable statistical test, the data were evaluated with several statistical tests. First, the Kolmogorov Smirnov Test was used to determine if the data were normally distributed. Then, a one way analysis of variance (ANOVA) test was used to check the homogeneity of the variance of the data. For the data fulfilling the parametric test assumptions, the ANOVA test was used to compare the groups. Otherwise, non-parametric statistical tests (a Mann-Whitney $U$ test was used for pairwise comparisons and a Kruskal-Wallis test was used to compare multiple groups) were used. For all of the tests, the significance level was taken as 0.05 .

\section{Economic analysis}

A "Partial Budget Analysis" was used to estimate the financial impacts of Se and Vit E supplementation on the diets. The "Partial Budget Analysis" method can evaluate small changes in the system. The analysis has 4 components: 1-new revenue, 2-cost saved, 3-revenue foregone, and 4new costs. If the sum of the new revenue and cost saved $(1+2)$ is greater than the sum of the revenue foregone and new costs $(3+4)$, the application of the alternative plan is financially recommended (Giles and Stansfield, 1990).

In this study, the technical findings that were statistically significant were taken into consideration in the partial budget analysis as follows:

i) New revenues from selenium supplementation included:
Table 2. Costs saved due to Se and Vit E supplementation

\begin{tabular}{lcc}
\hline & $\begin{array}{c}\text { Financial losses } \\
\text { due to clinical } \\
\text { metritis* }\end{array}$ & $\begin{array}{c}\text { Financial losses } \\
\text { due to sub-clinical } \\
\text { mastitis* }\end{array}$ \\
\hline $\begin{array}{l}\text { Treatment expenditures } \\
(\$ / \text { case })\end{array}$ & 63.9 & 72.8 \\
$\begin{array}{l}\text { Due to disease herd } \\
\text { the replacement cost } \\
(\$ / \text { case })\end{array}$ & 32.0 & 36.4 \\
Total $(\$ /$ case $)$ & & 109.2 \\
\hline
\end{tabular}

* The milk yield losses and extra insemination costs were deducted from the figures of Yalcin et al. (2006) to avoid double counting, as they were included in the cost of delay in calving intervals presented by Yalcin (2000).

a. The additional revenue resulting from the increased milk yield

b. The additional revenue (excluding that due to the increase in milk yield) from the decreased service period (hence the calving interval)

ii) Cost saved included the reductions of the incidence of sub-clinical mastitis and metritis, which include:

a. Treatment and culling costs saved due to the reduction of the incidence of sub-clinical mastitis and metritis

b. Insemination costs saved

iii) Revenue foregone: Not applicable in this study.

iv) New costs: the costs of $\mathrm{Se}$ and Vit $\mathrm{E}$ supplementation on the diets.

v) 1 US dollar was calculated as $2.28 £$

In the above analyses, the reduction in service period was assumed to cause the same level of reduction in the calving interval.

The findings of Yalçın (2000) were used to estimate the cost of delayed calving intervals, and the findings of Yalcin et al. (2006) were updated to 2014 market values to estimate the cost saved due to the supplementation (Table 2). The other financial data used in the partial budget analysis are presented in Table 3.

\section{RESULTS}

Se concentrations for each group are presented in Table

Table 3. Financial data used in the partial budget analysis

\begin{tabular}{lcl}
\hline Items & Price & Source of information \\
\hline $\begin{array}{l}\text { Raw milk producer price } \\
(\$ / \mathrm{kg})\end{array}$ & 0.5 & $\begin{array}{l}\text { National Milk Board of } \\
\text { Turkey, 2014 }\end{array}$ \\
$\begin{array}{l}\text { Savings resulting from } \\
\text { the shortening of CI }(\$ / \mathrm{d})\end{array}$ & 5.3 & Yalcin $(2000)$ \\
$\begin{array}{l}\text { Selenium application cost } \\
(\$ / \text { dose })\end{array}$ & 2.2 & Research findings \\
Semen cost $(\$ /$ dose $)$ & 26.3 & Average market price \\
\hline CI calving interval
\end{tabular}


Table 4. Selenium levels in serum $(\mu \mathrm{g} / \mathrm{L})$

\begin{tabular}{lccc}
\hline $\begin{array}{c}\text { Selenium } \\
\text { concentration }\end{array}$ & $\mathrm{C}$ & $\mathrm{T} 1$ & $\mathrm{~T} 2$ \\
\hline $\begin{array}{l}\text { Third week } \\
\text { before calving }\end{array}$ & $86.10 \pm 12.66$ & $83.28 \pm 5.35$ & $85.97 \pm 4.65$ \\
$\begin{array}{l}\text { Third day } \\
\text { after calving }\end{array}$ & $73.45 \pm 7.55^{\mathrm{a}}$ & $108.79 \pm 8.43^{\mathrm{b}}$ & $98.18 \pm 6.83^{\mathrm{c}}$ \\
$\begin{array}{l}\text { Values indicated with lowercase are different than other groups within the } \\
\text { row (p<0.05). }\end{array}$
\end{tabular}

4. Although the differences between the groups were not significant $(p>0.05)$ before calving, they were significant after calving (on the 3 rd day) $(\mathrm{p}<0.05)$.

Milk yields and conductivity values for each group are given in Table 5. The average milk yields and conductivity values of the cows in groups T1 and T2 were greater than those of the control group. Differences in milk yield at all weeks and the electrical conductivity values at the 8th and 12 th weeks were significant $(\mathrm{p}<0.05)$.

The effects of Se and Vit E supplementation on some postpartum diseases and fertility parameters are presented in Table 6. As seen in Table 6, all of the fertility and health parameters in the $\mathrm{T} 1$ and $\mathrm{T} 2$ groups were significantly lower than the $\mathrm{C}$ group $(\mathrm{p}<0.05)$, with the exception of the RFM values .

The technical and financial effects of Se and Vit $\mathrm{E}$ supplementation are presented in Table 7. As seen in Table 7, Se and Vit $\mathrm{E}$ supplementation makes a financial contribution of $240.6 \$ /$ cow in group T1 and 224.6 \$ cow in group T2. The major part of the financial gain comes from the increase in milk yield and the decrease in service period.

\section{DISCUSSION}

It has been reported that trace elements, such as Se, reduce oxidative stress, and that supplementation with these elements is important in periods of deficiency (Spears and Weiss, 2008; Sordillo and Aitken, 2009). Gerloff (1992) indicated that Se intake must be more than $6 \mathrm{mg}$ in order to achieve $70 \mu \mathrm{g} / \mathrm{lt}$ Se levels in the sera. The study of Abderrahman and Kincaid (1995) reported that Se concentration is decreased during the late pregnancy period.
Table 5. Milk yields and conductivity values in the three groups

\begin{tabular}{|c|c|c|c|}
\hline & Control & Treatment 1 & Treatment 2 \\
\hline \multicolumn{4}{|c|}{ Milk yield (week) } \\
\hline 4 & $32.0 \pm 6.05^{\mathrm{b}}$ & $35.6 \pm 6.66^{\mathrm{a}}$ & $35.2 \pm 6.69^{\mathrm{a}}$ \\
\hline 8 & $34.5 \pm 5.43^{\mathrm{b}}$ & $37.0^{\mathrm{a}} \pm 5.69$ & $37.3 \pm 5.73^{\mathrm{a}}$ \\
\hline 12 & $34.1 \pm 5.76^{\mathrm{b}}$ & $36.2 \pm 5.62^{\mathrm{a}}$ & $36.6 \pm 5.37^{\mathrm{a}}$ \\
\hline 16 & $33.5 \pm 5.32^{\mathrm{b}}$ & $35.9 \pm .15^{\mathrm{a}}$ & $35.7 \pm 5.13^{\mathrm{a}}$ \\
\hline \multicolumn{4}{|c|}{ Conductivity values (week) } \\
\hline 4 & $504.82 \pm 47.98$ & $503.93 \pm 39.60$ & $493.59 \pm 34.18$ \\
\hline 8 & $506.60 \pm 43.31^{\mathrm{b}}$ & $497.29 \pm 38.74^{\mathrm{ab}}$ & $489.26 \pm 37.48^{\mathrm{a}}$ \\
\hline 12 & $505.34 \pm 42.65^{b}$ & $495.59 \pm 39.14^{\mathrm{ab}}$ & $491.64 \pm 35.72^{\mathrm{a}}$ \\
\hline 16 & $499.65 \pm 46.61$ & $497.16 \pm 40.50$ & $492.17 \pm 33.17$ \\
\hline
\end{tabular}

Moenini et al. (2009) remarked that supplementation with Se and Vit E has several positive effects on heifers in late dry period, and that Se injection increases serum and colostrum Se concentration levels. In a study with sheep, Jalilian et al. (2012) reported a non-significant difference in serum Se levels between all groups before Se and Vit E supplementation during late pregnancy. However, they indicated that the serum Se levels were higher in treatment groups after lambing. Our results with serum $\mathrm{Se}$ concentrations are similar to those of these studies.

Both Se and Vit $\mathrm{E}$ decrease oxidative stress (Lacerata et al., 1996). Because of this, Se and Vit E supplementation is expected to increase milk yield in dairy cows (Phipps et al., 2008; Wang et al., 2009). Although Lacerata et al. (1996) and Moenini et al. (2009) reported statistically important differences in the effects of Se and Vit E supplementation on milk yield, the results of Bourne et al. (2008) were not significantly different $(p<0.05)$. The results of our study are in accordance with those of the first groups mentioned above.

Kommisrud et al. (2005) reported that the risk of mastitis is 1.3 and 1.4 times higher in herds with low Se levels in the first 30 days of lactation compared to herds with high Se levels. In the study of Machado et al. (2013), the sub-clinical mastitis ratio was 1 to 3 times higher in cows in control groups when compared with those treated with injectable trace elements (Se, Copper, Zinc, Mangenese). Some investigators reported an increase in somatic cell count and low resistance to clinical mastitis in

Table 6. The effect of selenium and vitamin E application on some postpartum diseases and fertility parameters

\begin{tabular}{lccc}
\hline & Control & Treatment 1 & Treatment 2 \\
\hline Service period & $91.7 \pm 29.5^{\mathrm{a}}$ & $79.1 \pm 26.3^{\mathrm{b}}$ & $81.6 \pm 20.4^{\mathrm{b}}$ \\
NSC & $1.90 \pm 0.9^{\mathrm{a}}$ & $1.58 \pm 0.8^{\mathrm{b}}$ & $1.62 \pm 0.7^{\mathrm{b}}$ \\
Sub-clinical mastitis $(\%)^{1}$ & $11(12 / 109)^{\mathrm{a}}$ & $3.7(4 / 107)^{\mathrm{b}}$ & $2.8(3 / 107)^{\mathrm{b}}$ \\
Metritis (\%) & $15.7(17 / 109)^{\mathrm{a}}$ & $5.6(6 / 107)^{\mathrm{b}}$ & $7.5(8 / 107)^{\mathrm{b}}$ \\
RFM $^{\mathrm{b}}(\%)$ & $4.6(5 / 109)$ & $2.8(3 / 107)$ & $2.8(3 / 107)$ \\
\hline
\end{tabular}

NSC, number of services per conception; RFM, retained fetal membrane.

${ }^{1}$ First 30 days after calving was evaluated.

${ }^{2}$ The RFM of cows more than $12 \mathrm{~h}$ were categorized as cows with difficulty in shedding placenta.

Values indicated with lowercase are different than other groups within the row $(\mathrm{p}<0.05)$. 
Table 7. Technical and financial effect of Se and Vit E application

\begin{tabular}{|c|c|c|c|c|c|c|c|c|}
\hline & \multirow{2}{*}{$\begin{array}{l}\text { Partial } \\
\text { budget }\end{array}$} & \multicolumn{3}{|c|}{ Treatment groups } & \multicolumn{2}{|c|}{ Difference } & \multicolumn{2}{|c|}{$\begin{array}{c}\text { Financial computation } \\
\$ / \text { cow }\end{array}$} \\
\hline & & $\mathrm{C}$ & $\mathrm{T} 1$ & $\mathrm{~T} 2$ & T1 & $\mathrm{T} 2$ & $\mathrm{~T} 1$ & $\mathrm{~T} 2$ \\
\hline Milk yield (kg/d)* & 1 & 33.5 & 36.2 & 36.2 & 2.7 & 2.7 & 143.2 & 144.6 \\
\hline Service period (days) & 1 & 91.7 & 79.1 & 81.6 & -12.6 & -10.1 & 66.9 & 53.6 \\
\hline Incidence of sub-clinical mastitis (\%) & 2 & 11.0 & 3.7 & 2.8 & -7.3 & -8.2 & 8.0 & 8.9 \\
\hline Incidence of metritis (\%) & 2 & 15.7 & 5.6 & 7.5 & -10.1 & -8.2 & 9.7 & 7.9 \\
\hline $\begin{array}{l}\text { Number of services per conception } \\
\text { (number/cow) }\end{array}$ & 2 & 1.90 & 1.58 & 1.62 & -0.32 & -0.28 & 8.4 & 7.4 \\
\hline Revenue foregone $(\$)$ & 3 & 0.00 & 0.00 & 0.00 & 0.00 & 0.00 & 0.0 & 0.0 \\
\hline Selenium application cost (\$/cow) & 4 & 0 & 2 & 1 & 2 & 1 & 4.4 & 2.2 \\
\hline Net profit (\$/cow) & & & & & & & 240.6 & 224.6 \\
\hline
\end{tabular}

C, control; T1, Treatment 1; T2, Treatment 2.

* 4 to 16 week average.

cows treated with trace elements (Smith et al., 1984; Erskine et al., 1987). The sub-clinical mastitis ratio in our study was 3 to 4 times higher in the control group than in treatment groups, which is in accordance with the literature.

A reduction in potassium and lactose levels causes the transfer of $\mathrm{Na}$ and $\mathrm{Cl}$ ions to milk from the blood in animals with mastitis, which causes an increase in the electrical conductivity of the milk (Nielen et al., 1992). Changes in electrical conductivity are reported to be a good indicator of udder health for the detection of sub-clinical mastitis (Hamann and Zecconi, 1998).

The effects of Se and Vit E supplementation on the incidence of mastitis and its mechanism have been previously reviewed. Adequate levels of Se and Vit $\mathrm{E}$ are reported to:

i) Increase phagocytosis, bacterial death, oxidative metabolism of peripheral blood and the number of neutrophils in the mammary glands (Sordillo and Streicher, 2002)

ii) Decrease the incidence of subclinical mastitis by enhancing the anti-oxidative defense mechanisms in the treated groups (Ceballoz-Marquez et al., 2010)

Postnatal reproduction performance is directly related to a healthy periparturient period. It has been reported that a troubled periparturient period causes increases in the incidence of postpartum uterus diseases in cows, including RFM, metritis and subclinical metritis, which decrease reproductive performance (Sordillo, 2013). In our study, Se and Vit E supplementation did not have a statistically important effect on the incidence of RFM, which is in accordance with the studies by Kommisrud et al. (2005) and Gupta et al. (2005). However, Harrison and Hancock (1999) and Moeini et al. (2009) reported a statistically important difference between treatment and control groups $(\mathrm{p}<0.05)$.

Clinical metritis is one of the most important postpartum diseases that affect reproductive performance.
Although some reports indicate that $\mathrm{Se}$ and Vit $\mathrm{E}$ supplementation in the prenatal period quickens the involution of the uterus in cows with clinical metritis (Harrison et al., 1986), no affirmative effects have been found on the intensity and incidence of uterus infections (Bourne et al., 2008; Cerri et al., 2009). Recent studies have indicated that systemic trace mineral supplementations considerably decrease uterus infections, especially metritis and clinical endometriosis, which involve Fusabacterium spp. and Trueperalla spp. (Bicalho et al., 2011; Machado et al., 2012; Machado et al., 2013). In addition, Harrison et al. (1984) mentioned that the incidence of metritis is decreased by Se supplementation in cows. In our study, the high incidence of metritis in the control group may be due to the following:

i) The high ratio of cows with RFM with metritis risk in the control group (Emanuelson et al., 1993; Roche, 2006)

ii) Improved defense system, especially with an increase in neutrophil functions by $\mathrm{Se}$ application in treatment groups (Ndiweni and Finch, 1996)

The calving interval is one of the most significant indicators of reproductive efficiency in dairy cattle. The service period must be under 100 days to achieve a calving interval less than 13 months. Therefore, the postpartum period must be concluded without any problems (Daşkın, 2005). Se is important for the reproductive functions of dairy cows. The use of supplemental Se in dairy cows with Se deficiency is reported to decrease the number of service per conception days and days open, and to increase the pregnancy rate at first service (Kommisrud et al., 2005). Arechiga et al. (1998) stated that Se and Vit E supplementation decreased number of service per conception days and days open in treated groups of dairy cows compared with a control group $(\mathrm{p}<0.05)$. Moenini et al. (2009) reported that $\mathrm{Se}$ and Vit $\mathrm{E}$ supplementation decreased the days open, but had no effect on the NSC. In 
addition, other studies designed with Se supplementation did not report effects on the number of service days per conception (Harrison et al., 1984) or fertility (Bourne et al., 2007). Our results indicating a decrease in the number of service days per conception and days open in treatment groups $(\mathrm{p}<0.05)$ supports the study of Arechiga et al. (1998).

This study used a partial budgeting technique, which revealed the economic consequences of $\mathrm{Se}$ and Vit $\mathrm{E}$ supplementation. Our results indicated high gains (about 230 \$/cow) in dairy herds with Se and Vit E supplementation. It was not possible to discuss the results of our study with others, as there is a lack of studies reporting the financial aspects of $\mathrm{Se}$ and Vit $\mathrm{E}$ supplementation.

\section{CONCLUSION}

Supplementation with Se and Vit E has been found to increase serum Se levels, milk yield, and has positive effects on udder health by decreasing milk conductivity values and incidence of sub-clinical mastitis. In addition, Se and Vit E supplementation decreased the incidence of metritis, the number of service days per conception and days open, but had no effects on the incidence of RFM. Partial budgeting analysis revealed that Se supplementation is economically profitable, with an increase of 240.6 \$ per head in T1 and 224.6 \$ per cow in T2.

\section{AUTHOR CONTRIBUTIONS}

T. Bayril and F. Akdemir conceived of the study, participated in its design and coordination, verification of data and helped draft the manuscript. M. Köse and O. Yilmaz participated in the verification of the data and helped draft the manuscript. A. S. Yildiz and C. Yalcin participated in collection of data and carried out descriptive statistics. All authors read and approved the final manuscript.

\section{CONFLICT OF INTEREST}

We certify that there is no conflict of interest with any financial organization regarding the material discussed in the manuscript.

\section{REFERENCES}

Abdelrahman, M. M. and R. L. Kincaid. 1995. Effect of selenium supplementation of cows on maternal transfer of selenium to fetal and newborn calves. J. Dairy Sci. 78:625-630.

Aréchiga, C. F., S. Vázquez-Flores, O. Ortiz, J. Hernandez-Ceron, A. Porras, L. R. McDowell, and P. J. Hansen. 1998. Effect of injection of $\beta$-carotene or vitamin $E$ and selenium on fertility of lactating dairy cows. Theriogenology 50:65-76.

Arslan, C. and T. Tufan. 2010. Nutrition of Transition in Dairy Cows I. Following this period of physiological, hormonal, metabolic, immunological changes and nutritional needs. Kafkas Univ. Vet. Fak Derg. 16:151-158.

Arthur, J. R., R. C. McKenzie, and G. J. Becket. 2003. Selenium in the immune system. J. Nutr. 133:1457S-1459S.

Bicalho, M. L. S., V. S. Machado, G. Oikonomou, R. O. Gilbert, and R. C. Bicalho. 2011. Association between virulence factors of Escherichia coli, Fusobacterium necrophorum, and Arcanobacterium pyogenes and uterine diseases of dairy cows. Vet. Microbiol. 157:125-131.

Bourne, N., R. Laven, D. C. Wathes, T. Martinez, and M. McGowan. 2007. A meta-analysis of the effects of Vitamin E supplementation on the incidence of retained foetal membranes in dairy cows. Theriogenology 67:494-501.

Bourne, N., D. C. Wathes, K. E. Lawrence, M. McGowan, and R. A. Laven. 2008. The effect of parenteral supplementation of vitamin $\mathrm{E}$ with selenium on the health and productivity of dairy cattle in the UK. Vet. J. 177:381-387.

Brzezinska Slebodzinska, E., J. K. Miller, J. D. Quigley, J. R. Moore, and F. C. Madsen. 1994. Antioxidant status of dairy cows supplemented prepartum with vitamin $\mathrm{E}$ and selenium. J. Dairy Sci. 77:3087-3095.

Ceballos-Marquez, A., H. W. Barkema, H. Stryhn, J. J. Wichtel, J. Neuman, A. Mella, J. Kruze, M. S. Espindola, and F. Wittwer. 2010. The effect of selenium supplementation before calving on early-lactation udder health in pastured dairy heifers. J. Dairy Sci. 93:4602-4612.

Cerri, R. L. A., H. M. Rutigliano, F. S. Lima, D. B. Araújo, and J. E. P. Santos. 2009. Effect of source of supplemental selenium on uterine health and embryo quality in high-producing dairy cows. Theriogenology 71:1127-1137.

Daşkın, A. 2005. Management of reproduction and artificial insemination in dairy farm. Aydan Web Ofset, Ankara. ISBN:975-00078-1-6.

Dogukan, A., N. Sahin, M. Tuzcu, V. Juturu, C. Orhan, M. Onderci, J. Komorowski, and K. Sahin. 2009. The effects of chromium histidinate on mineral status of serum and tissue in fat-fed and streptozotocin-treated type II diabetic rats. Biol. Trace Elem. Res. 131:124-132.

Emanuelson, U., P. A. Oltenacu, and Y. T. Gröhn. 1993. Nonlinear mixed model analyses of five production disorders of dairy cattle. J. Dairy Sci. 76:2765-2772.

Erskine, R. J., R. J. Eberhart, L. J. Hutchinson, and R. W. Scholz. 1987. Blood selenium concentrations and glutathione peroxidase activities in dairy herds with high and low somatic cell counts. J. Am. Vet. Med. Assoc. 190:1417-1421.

Gerloff, B. J. 1992. Effect of selenium supplementation on dairy cattle. J. Anim. Sci. 70:3934-3940.

Giles and Stansfield. 1990. The farmer as manager. Cab International ISBN: 0851986730.

Gupta, S., H. K. Gupta, and J. Soni. 2005. Effect of Vitamin E and selenium supplementation on concentrations of plasma cortisol and erythrocyte lipid peroxides and the incidence of retained fetal membranes in crossbred dairy cattle. Theriogenology 64:1273-1286.

Hamann, J. and A. Zecconi. 1998. Evaluation of the electrical conductivity of milk as a mastitis indicator. Bull. Int. Dairy 
Fed, No. 334.

Harrison, J. H., D. D. Hancock, and H. R. Conrad. 1984. Vitamin $\mathrm{E}$ and selenium for reproduction of the dairy cow. J. Dairy Sci. 67:123-132.

Harrison, J. H., D. D. Hancock, N. St. Pierre, H. R. Conrad, and W. R. Harvey. 1986. Effect of prepartum selenium treatment on uterine involution in the dairy cow. J. Dairy Sci. 69:1421-1425.

Harrison, J. H. and D. D. Hancock. 1999. Role of selenium and vitamin $\mathrm{E}$ deficiency in postpartum reproductive diseases. In: Honorary Lectures on Selenium and Vitamin E (Ed. A. L. Moxon). Wooster, OH, USA. pp. 85-99.

Jalilian, M. T., M. M. Moeini, and K. Karkodi. 2012. Effect of selenium and vitamin $\mathrm{E}$ supplementation during the late pregnancy on colostrum and plasma $\mathrm{Se}, \mathrm{Cu}, \mathrm{Zn}$ and $\mathrm{Fe}$ concentrations of fat tail SanJabi ewes and their lams. Acta Agric. Slov. 100/2:123-129.

Kommisrud, E., O. Osteras, and T. Vatn. 2005. Blood Selenium Associated with Health and Fertility in Norwegian Dairy Herds. Acta Vet. Scand. 46:229-240.

Lacetera, N., U. Bernabuci, B. Ronchi, and A. Nardone. 1996. Effects of selenium and vitamin $\mathrm{E}$ administration during a late stage of pregnancy on colostrum and milk production in dairy cows, and on passive immunity and growth of their offspring. Am. J. Vet. Res. 57:1776-1780.

Machado, V. S., M. L. Bicalho, R. V. Pereira, L. S. Caixeta, W. A. Knauer, G. Oikonomou, R. O. Gilbert, and R. C. Bicalho. 2013. Effect of an injectable trace mineral supplement containing selenium, copper, zinc, and manganese on the health and production of lactating Holstein cows. Vet. J. 197:451-456.

Machado, V. S., G. Oikonomou, M. L. S. Bicalho, W. A. Knauer, R. Gilbert, and R. C. Bicalho. 2012. Investigation of postpartum dairy cows' uterine microbial diversity using metagenomic pyrosequencing of the 16S rRNA gene. Vet. Microbiol. 159:460-469

Moeini, M. M., H. Karami, and E. Mikaeili. 2009. Effect of selenium and vitamin $\mathrm{E}$ supplementation during the late pregnancy on reproductive indices and milk production in heifers. Anim. Reprod. Sci. 114:109-114.

National Milk Board of Turkey. 2014. http://www. ulusalsutkonseyi.org.tr/ana/fiyat.asp?uid $=42$ Accessed 06 , 2014.

Ndiweni, N. and J. M. Finch. 1996. Effects of in vitro supplementation with $\alpha$-tocopherol and selenium on bovine neutrophil functions: Implications for resistance to mastitis. Vet. Immunol. Immunopathol. 51:67-78.

Nielen, M., H. Deluyker, Y. H. Schukken, and A. Brand. 1992. Electrical conductivity of milk: Measurement, modifiers, and meta analysis of mastitis detection performance. J. Dairy Sci. 75:606-614

NRC. 2001. Nutrient Requirements of Dairy Cattle. 7th ed. NationalAcademy Press, Washington, DC, USA
Phipps, R. H., A. S. Grandison, A. K. Jones, D. T. Juniper, E. Ramos-Morales, and G. Bertin. 2008. Selenium supplementation of lactating dairy cows: Effects on milk production and total selenium content and speciation in blood, milk and cheese. Animal 2:1610-1618.

Pryce, J. E., M. D. Royal, P. C. Garnsworthy, and I. L. Mao. 2004. Fertility in the high-producing dairy cow. Livest. Prod. Sci. 86:125-135.

Roche, J. F., D. Mackey, and M. D. Diskın. 2000. Reproductive management of postpartum cows. Anim. Reprod. Sci. 6061:703-712

Roche, J. F. 2006. The effect of nutritional management of the dairy cow on reproductive efficiency. Anim. Reprod. Sci. 96:282-296.

Smith, K. L., J. H. Harrison, D. D. Hancock, D. A. Todhunter, and H. R. Conrad. 1984. Effect of vitamin E and selenium supplementation on incidence of clinical mastitis and duration of clinical symptoms. J.Dairy Sci. 67:1293-1300.

Sordillo, L. M. and K. L. Streicher. 2002. Mammary gland immunity and mastitis susceptibility. J. Mammary Gland Biol. Neoplasia. 7:135-146.

Sordillo, L. M. and S. L. Aitken. 2009. Impact of oxidative stress on the health and immune function of dairy cattle. Vet. Immunol. Immunopathol. 128(1-3):104-109.

Sordillo, L. M. 2013. Selenium-dependent regulation of oxidative stress and immunity in periparturient dairy cattle. Vet. Med. Int Volume 2013, Article ID 154045, 8 pages, http://dx.doi.org/10.1155/2013/154045.

Spears, J. W. 2000. Micronutrients and immune function in cattle. Proc. Nutr. Soc. 59:587-594.

Spears, J. W. and W. P. Weiss. 2008. Role of antioxidants and trace elements in health and immunity of transition dairy cows. Vet. J. 176:70-76

Wang, C., Q. Liu, W. Z. Yang, Q. Dong, X. M. Yang, D. C. He, P. Zhang, K. H. Dong, and Y. X. Huang. 2009. Effects of selenium yeast on rumen fermentation, lactation performance and feed digestibilities in lactating dairy cows. Livest. Sci. 126:239-244

Wilde, D. 2006. Influence of macro and micro minerals in the periparturient period on fertility in dairy cattle. Anim. Reprod. Sci. 96:240-249.

Vanegas, J. A., J. Reynolds, and E. R. Atwill. 2004. Effects of an injectable trace mineral supplement on first-service conception rate of dairy cows. J. Dairy Sci. 87:3665-3671.

Yalçın, C. 2000. Financial losses resulting from infertility in dairy cattle. Lalahan Livest. Res. Inst. J. 40:39-47.

Yalçın, C., S. Sarızkan, A. S. Yıldız, and A. Günlü. 2006. Endemic diseases in dairy farm related Turkey Cattle Breeders Central Union and economic losses caused by the enterprise level. Ankara University Scientific Research Projects Office, Ankara, Turkey. 